\title{
THE EFFECT OF SOCIAL MEDIA AND FOREIGN TOURISTS' ATTITUDE TOWARDS PURCHASING DECISION MAKING OF SPA TOURISM PRODUCTS IN UBUD TOURISM AREA, GIANYAR DISTRICT
}

\author{
Ni Nyoman Suci Arthini \\ ${ }^{1}$ Sekolah Tinggi Pariwisata Nusa Dua Bali
}

\begin{tabular}{l} 
A R T I C L EI N F O \\
\hline Article history: \\
Received 19 April 2018 \\
Received in revised form \\
6 October 2018 \\
Accepted 12 October 2018 \\
Available online 20 October \\
2018 \\
\hline Keywords: \\
social media, attitude of \\
foreign tourists, making \\
decisions on purchasing \\
Spa tourism products
\end{tabular}

\begin{abstract}
A B S T R A C T
This study aims to determine the effect of social media and the attitude of foreign tourists on making purchasing decisions on Spa tourism products in Ubud Tourism Area, Gianyar Regency. Determination of the sample was done by Purposive Sampling. Sampling is done accidentally. The sample in this study was 105 foreign tourists who had bought or used Spa products in Ubud Tourism Area, Gianyar Regency. The methods of data collection in this study were observation and questionnaire. In this study the data analysis techniques used were descriptive analysis, simple regression analysis, and multiple linear regression analysis. Based on the research that has been done, it was found that: 1) social media (X1) had a positive and significant effect on purchasing decisions (y) Spa tourism products in the tourism area of Ubud by 4,295, 2) attitude (X2) had a positive and significant effect on purchasing decisions (y) Spa tourism products in the tourism area of Ubud at 6.680, and 3) social media (X1) Attitudes (X2) have a positive and significant effect on purchasing decisions (y) Spa tourism products in the Ubud tourism area of 98.992. From these findings it can be concluded that there are influences of social media and the attitude of foreign tourists towards making purchasing decisions on Spa tourism products in Ubud Tourism Area, Gianyar Regency.
\end{abstract}

\section{Introduction}

Bali is one of the most popular international tourist destinations in Indonesia. After 2015, Bali was named as the Best Travel Destination in Asia and Runner-Up of the World's Best Travel Destinations by Travel + Pleasure 2015 magazine, now Bali has been named the Top Best Honeymoon Destination 2016 after Santorini, Maldives, Bora Bora and Hawaii (https://m.tempo.co). The achievement of the award achieved by Bali sharpened Bali as a tourist destination icon in Indonesia. Minister of Tourism Arief Yahya is proud of Bali's achievements. This achievement complements a number of similar surveys held by other media or institutions.

The world's best island award for Bali is not the first time, that, Bali has become the top three of the world's best tourist islands by Travel and Leisure since 2009. Thus, a government-driven destination imaging strategy is starting to show results, and for 2016 and future promotion strategies and imaging continues.

From year to year the level of foreign tourist arrivals tends to increase from 2012 to 2016 to Bali. In 2012 Bali was only able to bring in 3,278,598 tourists (4.91\%) and this visit continued to experience a significant increase in 2015 which had been able to reach 4,001,835 tourists (6.24\%) until 2016 had reached $4,904,175$ tourists $(22,55 \%)$.

Bali as a destination known for its natural, cultural and artificial tourism also relies on alternative tourism as a motive for tourists to travel to Bali. One of the alternative tourism that is growing rapidly in 
Bali is a health and wellness tour, Spa. Bali as a health and wellness tourist destination has a name that is popular as one of the best Spa destinations and has won the title of The Best Destination Spa in the Asia and Wellness Gold Award Festival in Bangkok (The Jakarta Post; 2009), and The Best Spa in the World by Berlin Based Fitness Magazine Senses at the Annual International Tourism Bourse (ITB), Berlin in 2009. Bali has enormous potential for both asset wellness tourism namely (1) Existing assets for health and wellness tourism including natural assets, indigenous healing tradition, medical service, nature, and spiritual tradition, and (2) Use of existing assets including leisure and recreation, medical wellness center or Spa, holistic retreat, hotel and resort Spa.

According to Sastrayuda (2010 in Farrastri; 2015), Spa (Solus Per Aqua) is one part of wellness tourism. Daniela Matušíková (2010) added that limiting Spa services from various types of services that exist into 5 Spa services which are considered the most dominant and carried out are as follows; 1) Day Spa, 2) Hotel and Resort Spa, 3) Destination Spa, 4) Natural Bathing Spa and 5) Related Spa.

In the Global Spa Summit (2010) stated that Bali has become a leader in tourism Spa luxury in Asia, and almost all hotels in Bali offer world-class Spa facilities. Feel massage while enjoying the view from the top of the hill to the beach or to the mountains and countryside to become Spa characteristics in Bali in particular and in Indonesia in general. By relying on natural nuances of tropical nature and the appearance of traditional interior concepts, Bali has its own uniqueness in the Spa business (Anastasia, 2009: 29).

In Widjaya (2011) stated that one of the wellness main products, namely Spa in Bali, grew by more than 160\% within 8 years. From 2003 until 2011, there were identified around 410 spas operating and scattered in tourist activity centers. Among the several tourism areas, Ubud has a role and actively contributes as a host in providing Spa facilities with around 97 similar businesses (Spa and salon business data of Gianyar Regency, 2013).

Gianyar Regency in particular the tourism area of Ubud is one of the districts in Gianyar Regency as the center / tourism center which is the fastest growing. The tourism area of Ubud besides being known as a center of arts and creative industries born from Ubud artists who are very thick with local culture and wisdom, many also develop spas and have a very good potential for tourism in Spa because this tour requires a quiet atmosphere, calm atmosphere support, beautiful and friendly with the culture of the local community.

In the Ubud Tourism Area in 2016 there were 160 Spa businesses spread in 3 (three) villages in Ubud Subdistrict which is the most crowded level of Spa tourism activity in Ubud tourism areas namely Ubud Village, Sayan Village and Kedewatan Village. Ubud Village is the fastest growing in providing Spa facilities, which are 142 Spa businesses, while Kedewatan Village has 13 Spa and Sayan Village businesses for 7 Spa businesses (General Recreation and Entertainment Directory of Gianyar Regency, 2016). These results also show that the Spa industry in Ubud tourism area is experiencing a very significant development.

Spa industry as a tourism product that will be seeded in the future is very important to be well managed in maintaining the image of Ubud as a wellness tourist destination in the eyes of tourists, therefore efforts are needed to keep tourists who use Spa services fulfilled their needs and desires that end up creating purchasing decisions tourists on an ongoing basis (Putra, 2015).

In the tourism industry, Spa business is growing rapidly because now Spa has become a lifestyle or lifestyle of people in various countries and even throughout the world on their way to a destination. Spa products can be known by tourists from various sources, one of which is through social media, which is one of the means of promotion of a company, so tourists before making a decision to purchase tourism products Spa can communicate effectively with marketers (companies).

The psychological condition of a tourist on a product and / or tourism service greatly influences the behavior and attitudes in making decisions about the product. The more positive psychology of tourists in assessing a tourist product or service, the positive behavior of tourists will be towards decisions that will be taken later (Harsanti, et al. 2013). Entrepreneurs create and offer a variety of Spa tourism products in order to win the competition and in this fierce competition, only Spa businesses are able to innovate and always carry out continuous studies in making and marketing Spa products that are capable of survival (Partiyasa; 2010). By the way it is necessary to do research on the factors that tend to influence tourists towards making purchasing decisions for Spa tourism products as an output of one of the wellness tourism services in the tourism area of Ubud.

Factors that have a positive effect on tourist purchasing decisions on tourism products are service quality and tourism product attributes. In Agustina (2012), write a lot of research that shows a significant correlation between service quality and product attributes on tourist purchasing decisions. Besides being influenced by product factors, it needs to be studied further is the influence of internal factors originating from the tourists themselves in creating purchasing decisions on products Spa tour. Jacoby and Ohestnut 
(1978 in Rudyanto, 2012) stated that purchasing decisions can be measured by using the attitude approach. The attitude approach can reveal customer decisions from aspects of psychological involvement, favoritism and a sense of goodwill on service products (Oh, 1995 in Agustina; 2012).

Moreover, external factors that influence tourists' purchasing decisions on Spa tourism products are mediasocial influences as one of the external factors that need to be considered, because consumers will first look for information related to Spa products that are needed as a knowledge base for Spa products. and feel it is important to know the influence of social media and the attitude of foreign tourists on making purchasing decisions on Spa tourism products in the Ubud Tourism Area, Gianyar Regency. So, later the results of the analysis that can be used as consideration of Spa entrepreneurs in the tourism area of Ubud in making and marketing Spayang products refers to the purchase decision of tourists on Spa products.

\section{Methods}

In this study, the object of the research was the influence of social media and the attitude of foreign tourists on purchasing decisions on Spa tourism products in Ubud Tourism Area, Gianyar Regency. The location of the research was focused on three villages in Ubud Subdistrict, namely: Ubud Village, Sayan Village, and Kedewatan Village. Those villages were chosen because there are a lot of Spa businesses and tourism centers in Ubud tourism areas.

This study used qualitative data and quantitative data. Qualitative data were described by words or sentences in the form of information relevant to this research. Qualitative data used in this study included the general description and boundaries of the Ubud village, information about the development of the Spa in the tourism area of Ubud, the tourism potential of Ubud Spadi presented in the form of descriptions, drawings and tables. While quantitative data were in the form of numbers that can be calculated and obtained with certainty. In this study, the quantitative data included a list of Spa business listings from the Gianyar Regency Tourism and Culture Office, the number of spas in Bali, the number of samples used, processed data in the form of scores from questionnaires regarding the role of social media, tourist decisions and other similar data.

The sample determination was done by Purposive Sampling. Sampling is accidentally, where the sample taken is foreign tourists who accidentally encountered when the researchers conducted the study. The sample requirements in this study were the criteria of foreign tourists who have purchased or used Spa services for at least 2 times purchasing Spa products and foreign tourists who know about Spa products through social media. Based on the calculation above, the sample for this study took a sample of 105 foreign tourists who had purchased or used Spa products in Ubud Tourism Area, Gianyar Regency.

Data collection methods used in this study were observation and questionnaire. Observation was done both directly and indirectly towards the object of research. Instruments were observation sheet, observation guide (Noor, 2010: 140). The checklist was used to determine the geographical, demographic and topographic aspects of Ubud Tourism Area. Through this checklist, the basic data from the Ubud Tourism Area were collected and become the basis of this research report. While the questionnaire method was a method of data collection by arranging questions that were closed and also open and spreading the list of questions to respondents (tourists) who were sampled to obtain the necessary data that were used to answer problems related to purchasing decisions on Spa tourism products in tourism area of Ubud.

In order for the results of this study to be clearly seen, data analysis techniques were very much needed in this study. Data analysis techniques used in this study were quantitative analysis techniques. In this study the data analysis technique used were multiple linear regression analysis and that was calculated using a computer tool, namely the SPSS program (Statistical Package for the Social Science) to process the data.

\section{Findings and Discussion}

\section{The Effect of Social Media towards Purchasing Decision Making of Spa Tourism Products by Foreign Tourists}

The results of the first hypothesis test show that social media (X1) which is thought to be one of the independent variables that have a direct positive effect on purchasing decisions of Spa tourism products in Ubud has a positive and significant effect on purchasing decisions (y). With a significance value of 0,000 where this value is less than a $=0.05$ and tcount of 4.295 is greater than $t$ table of 1.659 . So from that social media variable is one of the factors that can influence tourists to make decisions on purchasing spa tourism products in Ubud. 
This research is in accordance with the research conducted by VIciana (2014) which states that advertising factors through social media is one of the factors that can influence tourists on purchasing decisions. Tourists will always look for information about social media before deciding to buy something, in this study looking for information on Spa tourism products. At present, any information is very quickly searched for and obtained. Of the 105 respondents there were 68 people stated that they got information about Spa tourism products in the tourism area of Ubud through the website. It proves that information is very quickly spread and more detailed with the existence of a website, all kinds of information can be known directly by tourists, one of which is information about Spa tourism products.

Social media according to Thirusen Naidoo (2011: 46) and Bagus Riyanto and Ati Harmoni, 2013: 3 ) some common elements that need to be considered in social media advertisements are drawn: persuasion, trust, appearance and impact.

Thus social media factors have a positive and significant effect on purchasing decisions of Spa tourism products with all indicators acceptable to tourists, which later can be used as an excuse to make decisions in purchasing Spa tourism products.

\section{The Effect of Attitude towards Purchasing Decision Making of Spa Tourism Products by Foreign Tourists}

From the results of this study it was found that attitudes (X2) showed that the attitude of tourists consisting of trust, likes and actions influenced the purchasing decisions (y) Spa tourism products in the tourism area of Ubud. With a significance value of 0,000 where this value is less than $a=0.05$ and tcount of 6.680 is greater than $t$ table of 1.659 . Therefore the attitude variable is one of the factors that can influence tourists to make decisions on purchasing Spa tourism products.

The attitude that is the result of the interaction of cognitive, affective and conative components often influences the decision whether consumers want to consume or not. Wee, et al., 1995 (in Trisdiarto, 2012) also stressed that attitudes play an important role in tourist purchasing decisions and survive on these products (retention). The existence of a more positive attitude towards goods or services, it will increase the purchase of goods or services. As well as the increasingly negative attitude of consumers to goods or services, it will be less likely for these consumers to make a purchase. Positive and negative attitudes are obtained from the knowledge of the product and previous purchasing experience, so that trust is formed, fosters emotional feelings and shows a tendency to take action (Mowen and Minor; 2012).

To measure attitudes can be done with the form of cognitive, favorite (affective) and tourist actions (conative), (Syafril; 2008). That is, the sub-variable of trust is the one that dominates the attitude of tourists in making decisions on purchasing Spa tourism products.

These results are consistent with the results of previous studies conducted by Wahyuni (2008) and Garry (2011). The results of the discussion concluded that attitudes are variables that influence consumer purchasing decisions.

\section{The Effect of Social Media and Attitude towards Purchasing Decision Making of Spa Tourism Products by Foreign Tourists}

From the results of this study it was found that social media (X1) attitude (X2) had a positive and significant effect on purchasing decisions (y) Spa tourism products. With a significance value of 0,000 where this value is less than $\mathrm{a}=0.05$ and the count is 98.992 greater than ftabel of 3.08. So from that social media variables and attitudes influence simultaneously on purchasing decisions of Spa tourism products in the tourism area of Ubud.

Social media and attitudes are two factors that can influence tourists in wisaata Spa product purchasing decisions. Social media and attitudes are the factors seen when searching for information about Spa tourism products before making a decision to purchase Spa products.

These two factors are mutually mutually proven Spa efforts in the tourism area of Ubud which consists of 3 (three) villages, namely in Kelurahan Ubud, Kedewatan Village and Sayan Village is one of the excellent locations for Spa tourism because these locations have advantages the right area and can be combined with the quality of Spa products. This is the first step that is always seen by tourists in making purchasing decisions. Thus the third problem formulation of this study has been answered, that social media factors and attitudes simultaneously have a positive and significant effect on purchasing decisions of Spa tourism products in the tourism area of Ubud. 


\section{Conclusion}

Based on the results of the research that has been done the following results are obtained.

1. Social media (X1) has a positive and significant effect on purchasing decisions (y) Spa tourism products in the tourism area of Ubud by 4,295 . The most influential sub-variable is the persuasion of the statement that is social media information is very clear and easy to use with an average score of 4.14, which in other words tourists agree with the statement of the indicator.

2. Attitude (X2) has a positive and significant effect on purchasing decisions (y) Spa tourism products in the Ubud tourism area of 6.680. The most influential sub-variable is the belief of Spa product statements can reduce stress levels with an average score of 4.35 where in other words tourists say strongly agree with the statement.

3. Social media (X1) Attitude (X2) has a positive and significant effect on purchasing decisions (y) Spa tourism products in the Ubud tourism area of 98.992. So social media and attitude have an influence on tourists to make their decisions in purchasing Spa tourism products.

For the results of this study, the suggestions that researchers can submit are as follows.

1. It is important for Spa businesses in the Ubud tourism area to further evaluate the social media used by Spa businesses because the influence of social media on purchasing decisions is lower than the influence of attitudes. From the findings on the field, some Spa businesses in Ubud Tourism Area use a lot of Quality Of Services or quality service as a promotional tool. This does not mean that Spa businesses in the Ubud Tourism Area do not use social media as an effective promotional tool but Spa efforts in the Ubud tourism area need to look at each of the 4 subvariables used in this study. It is expected that tourists will remember one or two names such as the logo or color of the Spa product brand on social media that can remind them of the Spa business in Ubud when they come to Bali or visit Ubud in particular. It can also be a branding of Ubud as a health and wellness tourism area popular in Bali.

2. The number of Spa businesses is predicted to increase in line with the increasing demand for Spa products. It is very necessary for regulations and policies of the Gianyar regency government, namely the Gianyar Regency Tourism Office related to regulation and standardization, especially related to the price and quality of Spa products in Ubud which currently tend to experience unhealthy competition. Many spas provide cheap prices for a measure of tourism services. This condition will certainly threaten the quality of Spa tourism services that will be given to tourists later.

\section{References}

Agustina, Vina. Analisis Pengaruh Kualitas Pelayanan, Kualitas Pelanggan, dan Nilai Pelanggan dalam Meningkatkan Loyalitas Pelanggan Joglosemar Bus (Studi pada Wilayah Semarang Town Office). Laporan Skripsi. Fakultas Ekonomika dan Bisnis Universitas Diponegoro).

Anastasia, Henny. 2009. Cantik, Sehat, dan Sukses Berbisnis Spa. Penerbit : Kanisius.

Farrastri, R.A Niken, 2015. Analisis Jenis Gaya Hidup Wisatawan Di Griya Spa Putri Kedaton. Yogyakarta : Skripsi Fakultas Ilmu Budaya Universitas Gadjah Mada.

Garry, Imancezar R. 2011. Analisis Pengaruh Motivasi Konsumen, Persepsi Konsumen, Dan Sikap Konsumen Terhadap Keputusan Pembelian (Studi Pada Distro Districtsides di Semarang). Laporan Akhir. Fakultas Ekonomi Universitas Diponegoro.

Matušíková, Daniela. 2010. Health Tourism. Prešov in Prešov : GRAFOTLAČ PREŠOV.

Mowen, J dan Minor, M. 2002. Perilaku Konsumen Jilid I Edisi Kelima. Jakarta: Erlangga

Naidoo, Thirushen. 2011. The effectiveness of advertising through the social media in Gaunteng. Journal of Advertising Research. 49(3), 46.

Partiyasa, Wayan. 2010. Kecenderungan Faktor-Faktor yang Mempengaruhi Wisatawan Mancanegara dalam Membeli Paket Wisata pada Biroperjalanan di Kodya Denpasar Provinsi Bali. Jurnal Ilmiah 
Hospitality Management Vol 1, No 1, hal 18-30. Pemerintah Kabupaten Gianyar. Dinas Pariwisata Kabupaten Gianyar.

Trisdiarto, Hendro T. 2012. Pengaruh Faktor Sosial dan Personal terhadap Sikap dan Niat Beli Konsumen untuk Barang Fashion Palsu di Kota Denpasar dan Kabupaten Badung. Laporan Tesis. Program Pascasarjana Universitas Udayana.

Wahyuni, Dewi Urip. 2008. Pengaruh Motivasi, Persepsi Dan Sikap Konsumen Terhadap Keputusan Pembelian Sepeda Motor Merek "Honda" Di Kawasan Surabaya Barat. Jurnal Manajemen dan Kewirausahaan, Vol. 1. No. 1. Hal.30-37.

Widjaya, Lulu. 2011. Spa Industry di Bali. Guest Lecture Program Doktor Kajian Pariwisata di Universitas Udayana. 